\title{
Alguns aspectos simbólicos acerca do gato
}

\section{Andréa Osório}

Universidade Federal Fluminense

E-mail: andrea_osoriol@yahoo.com.br 


\section{Resumo}

Baseado nas concepções de Edmundo Leach (1983) sobre o status ambíguo de certas categorias de animais, este ensaio soma dados historiográficos e análises antropológicas para apontar alguns aspectos simbólicos relacionados aos gatos domésticos. Animal utilizado em rituais, associado ao sobrenatural, o gato parece particularmente ambíguo. Procura-se apontar onde residem tais ambiguidades e contribuir, em algum grau, para os debates acerca das relações humano-animal.

Palavras-chave: Gato. Simbolismo. Relação humano-animal.
Abstract

Based on the ideas of Edmund Leach (1983) on the ambiguous status of certain categories of animals, this paper adds historiographical data and anthropological analysis to point out some symbolic aspects of the domestic cats. Animal used in rituals associated with the supernatural, the cat seems particularly ambiguous. The paper aims to show such ambiguities and to contribute in some degree to the debates about human-animal relations.

Keywords: Cat. Symbolism. Human-animal Relations.

ILHA

volume 12 - número 2 


\section{Introdução}

$\mathrm{O}$ presente ensaio pretende-se uma reflexão sobre alguns aspectos simbólicos relacionados ao gato na literatura antropológica e em algumas obras historiográficas. Como argumento geral, aponta-se como o gato é um animal ambíguo e rico simbolicamente. Poucas obras antropológicas dedicam-se a falar mais do que uma ou duas linhas sobre gatos. Nenhuma literatura brasileira foi encontrada especificamente sobre eles, mas uma menção especial e necessária é a de DaMatta e Soárez (1999), cuja obra acerca do jogo do bicho no Brasil elabora uma análise sobre o simbolismo que envolve alguns animais do jogo. Exceção geral também é o ensaio historiográfico de Darnton (1986).

O objetivo é compreender alguns aspectos simbólicos relacionados a esse animal. Para tanto, a análise está fortemente ancorada na discussão clássica de Leach (1983) acerca da posição estrutural de certos animais ante o ser humano. Como a maioria da bibliografia levantada acerca do gato, conquanto escassa, está ancorada nesse paradigma, soará ao leitor que há uma espécie de consenso. Contudo, deve-se apontar tal como uma abordagem coesa em termos de paradigma. Nesse sentido, o ensaio ora proposto tem mais a qualidade de um "estado da arte" sobre o simbolismo do gato na literatura existente.

O paradigma estruturalista de Leach (1983) está em oposição ao funcionalista. O funcionalismo, como aponta Sperber (1975), manteve como preocupação principal a utilidade de certos animais, o que foi jocosamente apontado por Lévi-Strauss como o "bom para 
comer", ao passo que a abordagem lévi-straussiana primou pela ideia de que os animais são "bons para pensar". Para Sperber, essa dimensão influenciou os trabalhos tanto de Douglas (1976) quanto de Leach. Nesse sentido, é a esse "bom para pensar" que o presente ensaio se destina, embora uma parte reduzida da bibliografia consultada apresente explanações do tipo funcionalista.

A reflexão está estruturada a partir dos eixos apontados por Leach (1983), que incluem: a comestibilidade como algo que permite pensar sobre os animais e sua carga simbólica, como também fez Sahlins (1979); as categorias animais como insulto (ou elogio) e as corruptelas verbais associadas a categorias animais; e a noção de que certas categorias animais ocupam posições ambíguas.

Os dados historiográficos são somados, neste trabalho, às análises antropológicas como exemplos de interpretações de uma realidade passada que pode ou não se manter viva nas concepções atuais. Em alguns momentos, somam-se dados empíricos levantados por pesquisadores da área de veterinária e educação ambiental. Tais dados não apontam, contudo, que as percepções, crenças e representações acerca do gato têm fundamento no que Douglas (1976) chamou de materialismo médico, mas indícios que julguei relevantes para apontar como concepções e ideias àquilo que se apresenta, no senso comum, como fato material.

\section{A abordagem leachiana}

Leach (1983) empreende uma tarefa de fôlego ao estruturar séries de correspondência entre comestibilidade animal e relações de parentesco/afinidade e tem sido obra de referência frequentemente encontrada em estudos acerca do simbolismo animal. Portanto, e antes de tudo, faz-se necessária uma pequena introdução às considerações do autor. Segundo Leach, a linguagem obscena faz uso extenso de categorias animais, porém nem todo animal se presta ao insulto. Não é o animal em si ou sua essência que definem seu uso como insulto, mas esse uso indica que o nome do animal possui algum poder e, portanto, a categoria animal é tabu e sagrada. Para uma melhor compreensão do status de sagrado, Leach indica que 
alguns animais são foco de rituais, enquanto outros não, e que as categorias de comestibilidade do animal também são relevantes nesse sentido.

Empreendendo uma tipologia do grau de sacralidade/tabu e comestibilidade do animal, o autor aponta para três possibilidades: comestíveis e consumidos normalmente; comestíveis e consumidos em situações especiais (conscientemente tabu); ou comestíveis, porém não reconhecidos como comida (inconscientemente tabu). Está claro que, para o autor, a comestibilidade em questão é material (venenoso/não venenoso), mas o reconhecimento como comida está no plano simbólico. O exemplo dado por ele é a proibição do consumo de carne suína na religião judaica: o porco é comestível, mas não é comida para os judeus. Também recaem nessa divisão, como aponta, os animais que, sendo tão próximos ao homem que se tornam do mesmo tipo, não podem ser ingeridos sob o perigo do canibalismo, como seria o caso do cachorro.

Da série de comestibilidade Leach (1983) depreende uma associação entre incesto/canibalismo e sexo/alimentação. Decorrem daí as seguintes séries: a) eu, irmã, primo(a), vizinho(a), estranho(a); b) eu, casa, fazenda, campo, longínquo (remoto); e c) eu, animal de estimação (pet), gado (animais de criação), caça, animais selvagens. As três séries devem ser lidas também na vertical: por exemplo, a relação com as pessoas de dentro da casa e com quem não posso me casar (irmã) fornece o padrão de relação que mantenho com meus animais de estimação. O objetivo central do exercício é depreender uma regra que diz que o tabu se aplica a categorias anômalas, quando em relação a categorias bem delimitadas, numa conclusão similar à de Douglas (1976) e a de Hubert e Mauss (2001, p. 143) sobre "o caráter ambíguo das coisas sagradas". Em outra série, Leach indica que homem (animais domesticados)/não homem (animais selvagens) e, na interseção desses dois conjuntos, ou seja, em posição anômala, estão animais de estimação (caça).

A relevância de se indicar o argumento leachiano é compreender a posição anômala que os animais de estimação ocupam na sociedade ocidental contemporânea. Entre tais animais, o gato parece ocupar uma posição especialmente anômala, o que pode ser sugeri- 
do a partir das ambíguas restrições ao consumo de sua carne no Brasil (churrasco de gato), aos seus poderes sobrenaturais (sete vidas, gatos pretos que trazem má sorte), à sua ocupação preferencial de territórios liminares (muros, telhados, dentro e fora das casas) e à sua condição de não totalmente domesticado, posto que ele caça (ratos) e não obedece a ordens como cães e cavalos, por exemplo. Esses pontos serão abordados ao longo deste ensaio.

\section{Magia e sacrifício ritual}

Uma obra que é exceção à parca análise sobre gatos é $O$ grande massacre de gatos e outros episódios da história cultural francesa (Darnton, 1986). Remetendo-se ao debate douglasiano sobre a ingesta do porCo (Douglas, 1976) e às categorias animais conforme debatidas por Leach (1983), Darnton (1986) sugere que a posição ambígua dá a alguns animais (como o gato) um poder associado ao tabu e, portanto, um valor ritual. Segundo Darnton, gatos eram um tema recorrente de rituais e de simbolismo popular na França. A tortura e a morte ritual de gatos faziam parte de passeatas burlescas (charivaris) e da Terça-Feira Gorda do Carnaval tanto quanto das festas juninas e do Corpus Christi, mas também em certos episódios fora da França, como na Alemanha e na Inglaterra. A caça aos gatos nessas situações festivas, diz o autor, assemelhava-se a uma caça às bruxas, incluindo a queima ritual em fogueira.

A tortura de animais, especialmente os gatos, era um divertimento popular em toda a Europa, no início dos Tempos Modernos. [...] Os franceses, no início dos Tempos Modernos, provavelmente usaram mais os gatos, em nível simbólico, do que qualquer outro animal, e usavam-no de maneiras diferentes (Darnton, 1986, p. 121-125).

Segundo Cohen (1994), na Idade Média animais vivos faziam parte de procissões públicas. Em Ypres, havia uma 'festa dos gatos' na segunda quarta-feira da Quaresma. Originalmente, diz a autora, consistia em procissão seguida pelo lançamento de gatos do alto de uma torre. Uma cerimônia que queimava gatos, afirma ainda, era celebrada em Paris, todos os anos, na véspera do Dia de São João 
como parte das tradicionais fogueiras do ciclo junino. Uma pira era erguida e dúzias de gatos em sacos eram suspensos sobre ela. Cohen se pergunta se os maus-tratos aos gatos eram mero sadismo e aponta que tais maus-tratos eram públicos, ritualísticos e que os animais, especialmente os domésticos, serviam como um reflexo da comunidade humana e seu bode expiatório. O massacre de gatos, ao coincidir com rituais de limpeza, tornava o gato um animal sacrificial.

Hyams (1972) afirma que nenhum outro animal teria sofrido tanto quanto o gato doméstico na Europa Medieval. Na Europa Central, na Alemanha e em Flandres, diz o autor, durante a Quaresma era costume matar, queimar ou enterrar vivos tantos gatos quanto fosse possível. Durante a Páscoa, no Vosges e na Alsácia em geral os gatos eram regularmente queimados vivos. Nas montanhas de Ardennes, eles eram jogados vivos em fogueiras ou assados vivos presos em postes. A razão seria sua identificação com Satã. Segundo o autor, tais práticas seriam ritos mágicos cuja intenção era espantar o diabo.

Nos séculos XVI e XVII, ainda segundo Hyams (1972), em toda a Europa e na América (presumivelmente nos Estados Unidos), colocavam-se gatos vivos, mortos ou mumificados nas paredes ou sob o piso das casas, às vezes junto a um rato. O autor então se pergunta por que um animal útil, já que caça ratos, seria considerado medonho. A resposta que fornece, além de suas ligações com o diabólico, seria seu status de animal novo e recém-chegado na Europa, o que teria lhe valido uma reputação ambígua. Para sustentar tal argumento, Hyams demonstra que nem sempre o gato foi um animal doméstico comum no continente, mas que sua introdução ali teria se dado após uma praga de ratos oriunda de levas migratórias germânicas. Além disso, certas características atribuídas ao gato como hábitos noturnos, sua associação com a lua e seus "olhos enigmáticos" teriam contribuído, além de sua "autossuficiência".

Esses aspectos claramente ritualísticos do gato apontam para sua sacralidade e são corroborados por um ritual descrito por Hyams (1972) no qual, em vez de ser destruído, o gato era adorado. Segundo o autor, no festival do Corpus Christi de Aix en Provence, o gato 
macho mais bonito da região era embrulhado em tecido como uma criança e exibido publicamente, quando os habitantes locais se ajoelhavam e erguiam flores e incenso, "e, em resumo, o gato nesta ocasião era tratado como o deus do dia" (p. 45, tradução minha).

Para Darnton (1986), as razões simbólicas do uso ritual do gato residiriam numa correlação entre os gatos e a feitiçaria. Toda uma série de formas de torturar gatos consistia, na verdade, em livrar-se da feitiçaria ou das feiticeiras. Dado esse poder, os gatos também impediam tarefas cotidianas de transcorrerem bem, como o crescimento do pão ou a pescaria, ou serviam para impedir eventos nefastos, como o crescimento das urtigas. Seu uso ritual e mágico para atividades consideradas moralmente boas ou ruins indica a ambiguidade do animal. Simbolicamente, era a sua correlação com o sobrenatural que o tornava propício a práticas mágicas.

Para Mauss (2003), entre as diferenças encontradas entre magia e religião, uma delas refere-se, exatamente, ao sacrifício, que está associado à religião, ao passo que o malefício é associado à magia. Nesse sentido, os ritos acima elencados são ritos religiosos em que se sacrificam gatos, que, não obstante, são também usados nos ritos mágicos. O sacrifício, segundo Hubert e Mauss (2001), pode tomar diversas formas. São sacrificados tanto animais quanto alimentos de origem vegetal e deuses, estes na forma de humanos, de animais ou de vegetais. Nos casos elencados acima de sacrifícios de gatos, como o ritual é descrito superficialmente, não é possível uma análise mais aprofundada, a não ser a indicação de que se trata de uma espécie de bode expiatório ou, no ritual descrito por Hyams (1972), um substituto do deus.

Segundo Mauss (2003, p. 72), a relação entre magia e animais é bastante comum:

a antiga strix, é uma feiticeira e uma ave. Depara-se com a feiticeira fora de casa sob a forma de gato preto, de loba, de lebre, com o feiticeiro sob a forma de bode etc. quando o feiticeiro ou a feiticeira deslocam-se para causar dano, eles o fazem sob sua forma animal, e é nesse estado que se pretende surpreendê-los. [...] As feiticeiras européias, em suas metamorfoses, não assumem indiferentemente todas 
as formas animais. Elas se transformam regularmente, uma em jumento, outra em rã, outra ainda em gato etc.

O gato preto também é relacionado, no Brasil, à prática de magia e diz-se que traz má sorte. No entanto, nossas crenças mágicas não pretendem que bruxas e feiticeiros transformem-se em animais. É interessante contrastar os animais elencados na citação acima com as séries elaboradas por Leach (1983): se a lebre, a rã e o gato são facilmente classificáveis como ambíguos, a loba, o jumento e o bode não o são. Além disso, é o gato preto que é relacionado, especialmente, mas não somente, à magia e ao diabo (Hyams, 1972). Hubert e Mauss (2001) indicam como o preto esteve relacionado a divindades ctônicas e relatam sacrifícios de vacas negras e cavalos negros para fazer chover, ou rituais que envolvem galos negros para afastar a má sorte. Embora não se possa depreender daí uma lei geral sobre o uso das cores em rituais ligados a cosmologias distintas, é interessante marcar que as cores apresentam um simbolismo.

Nos casos apontados pelo autor, e dentro de sua teoria geral da magia, "o poder mágico se deve, nesses diversos casos, à sua familiaridade com animais" (Mauss, 2003, p. 73), isto é, uma aliança entre o mágico e o animal. Embora frequentemente se trate de um animal em especial, Mauss indica que, "com muito raras exceções, não é com um animal em particular, mas com uma espécie animal inteira que o mágico tem relações. Desse modo, já, estas se assemelham às relações totêmicas" (p. 73), quando o animal é tomado como totem individual e não se pode mais consumir sua carne. Mauss aponta, ainda, que "o mágico é definido por suas relações com os animais, assim também ele é definido por suas relações com os espíritos" (p. 76).

Espíritos e animais se confundem, ao que parece, na medida em que se trata de animais mágicos, individualmente dotados de poderes espirituais específicos (ou mana), e não de categorias animais, conforme indica a abordagem leachiana. A análise maussiana, embora certamente uma inspiração para o arcabouço estruturalista que viria depois, não chega às mesmas conclusões. Já que se está privilegiando a abordagem estruturalista de Leach (1983) no presente ensaio, acredito que a ressalva seja necessária. Observe-se que 
Mauss (2003) não cria categorias anômalas para tais animais nem tenta explicar por que esses e não outros. Limita-se, nesse ponto, a uma coleta de dados históricos, religiosos e folclóricos que lhe permita construir uma lei geral na qual os animais aparecem como instrumentos ou metamorfoses dos mágicos para, ao fim, recair no conhecido problema do totemismo.

Embora Mauss (2003) indique como a magia opera a partir de inversões dos ritos religiosos, a própria metamorfose do mágico em animal não é apontada claramente por ele como uma dessas inversões que, para ser considerada como tal, necessita estar ancorada numa separação entre homem/animal e natureza/cultura. Mauss também aponta como os mágicos são pessoas especiais, extraordinárias, mesmo quando uma população inteira é considerada assim, como, por exemplo, os judeus diante do catolicismo medieval e os estrangeiros em geral. Não decorre dessa conclusão, tampouco, uma pergunta sobre o status especial dos animais vinculados à magia, o quão extraordinários eles seriam, conclusão que só é trazida à tona a partir das análises estruturalistas.

\section{Animais de estimação}

Antes de serem animais de estimação, como apontam Hyams (1972) e Thomas (1988), os gatos foram classificados como de natureza vil. Não obstante, nos navios eram considerados parte da tripulação, junto com os cães.

Na Idade Média, eles eram criados em casa, para combater ratos e camundongos. É bem ocasional que apareçam como companheiros e objetos de afeição [...]. Muitos chefes de família eximiam-se deliberadamente de alimentá-los, de modo a garantir que tivessem um incentivo para caçar. [...] No entanto, ao começar o período Stuart [século XVII] já eram numerosos os amigos dos gatos (Thomas, 1988, p. 131).

Serpell e Paul (1994) indicam que gatos e alguns pássaros eram os únicos animais permitidos em conventos franciscanos, pois eram vistos como úteis na manutenção da limpeza, numa explicação claramente funcionalista. Segundo Thomas (1988), no reinado de Carlos 
II (1660-1685), a maioria das famílias londrinas possuía pelo menos um gato. Não obstante, foi nesse período que procissões antipapistas queimavam gatos vivos. Só no século XVIII o gato consolidou sua posição de animal de estimação: "é provável que o gato tenha adquirido popularidade à medida que se elevavam os padrões de asseio doméstico", afirma Thomas (1988, p. 133) ao estilo funcionalista. Segundo esse autor, um vendedor de comida de gato de meados do século XIX chegou a afirmar que havia um gato para cada dez pessoas em Londres e que seu contingente era o dobro do canino. Indica, também, que a primeira exposição de gatos na Inglaterra deu-se em 1871. Antes dos gatos, a Europa teria usado o furão como caçadores de ratos (Hyams, 1972). Domesticado no Egito no segundo milênio a.C., o gato doméstico seria o cruzamento de espécies selvagens domesticadas ou não, introduzidas a partir de levas migratórias germânicas.

A presença habitual de animais de estimação nos lares ingleses, segundo Thomas (1988), consolidou-se entre os séculos XVI e XVII. Contudo, Ritvo (1987) afirma que a popularidade desses seria uma característica do século XIX. Antes disso, aqueles que demonstravam afeto por seus animais de estimação eram vistos de forma negativa. Uma das características do animal de estimação, para a autora, era sua função como objeto de afeto, ao contrário de animais que deveriam trabalhar, como cães pastores, animais de tração, entre outros. Essa separação entre animais que trabalham e os que não trabalham é uma representação da relação entre as classes (elite e trabalhadores). Nesse sentido, Ritvo indica que animais de estimação eram vistos como um privilégio de classes abastadas, incluindose a classe média. Nas classes trabalhadoras, a existência de animais de estimação era má vista, reforçando noções de sujeira e insalubridade relacionadas a essas classes.

A autora sugere, ainda, que a relação com o animal de estimação, sobretudo na invenção e na criação de raças de cães para concursos, era, no século XIX, uma relação de controle sobre a natureza. Assim, para controlar a natureza (ter um animal de estimação), aparentemente um homem deveria antes dominar outros homens 
(pertencer à elite). Pesa, ainda, nesse novo tipo de relação com os animais a emergência da ciência como uma forma de explicação e domínio da natureza pelo homem. A análise de Ritvo (1987) equaciona, portanto, um viés de classe com uma nova configuração social na qual a relação natureza e cultura é distinta: de ameaça à sobrevivência humana, diz ela, a natureza passa a objeto de especulação e dominação através do conhecimento científico. É nessa nova relação com a natureza que a sociedade inglesa passa, segundo a autora, a adotar de forma positiva animais de estimação.

Serpell (1987), por outro lado, afirma que a associação entre animais de estimação e elite é ilusória. Segundo o autor, há farta indicação de que a realeza britânica fosse entusiasta dos animais de companhia, mas sua existência entre as classes populares não deve ser ignorada. O argumento de Serpell aponta para um discurso no qual a elite é acusada de preferir animais de estimação a seres humanos das classes trabalhadoras, criando assim uma associação entre tais animais e uma vida de ostentação desnecessária e imoral. De certa maneira, o próprio animal de estimação animalizava a elite, apresentada como uma classe desumana. Todavia, as classes populares europeias mantinham animais de estimação cuja existência, durante o período inquisitorial, podia ser interpretada como prática de bruxaria, baseada na noção mágica de familiar, que se refere, como afirma Mauss (2003, p. 72-73), a "um auxiliar familiar do qual a feiticeira permanece distinta. Assim é o gato Rutterkin das feiticeiras Margaret e Fillipa Flower, que foram queimadas em Lincoln, no dia 11 de março de 1619". Não sabemos o que houve com o gato.

Enquanto Ritvo (1987) analisa um discurso sobre os pobres e os animais de estimação no século XIX, Serpell (1987) aponta para um discurso sobre ricos e animais de estimação na Grécia Clássica, no Império Romano e na Europa Medieval, entre outros. O conteúdo parece ser o mesmo: a presença do animal de estimação animaliza seu proprietário, tornando-se uma metáfora dele. Essa antipatia pela sua presença nos lares europeus, segundo Serpell, não seria oriunda de considerações econômicas pela vida dos pobres ou dos ricos, mas de preocupações de cunho moral. É curioso comparar esses discursos com as análises mais atuais (Kulick, 2009, por exemplo) nas quais 
a presença de animais de estimação nos lares urbanos ocidentais humaniza tais animais. São, certamente, representações diferentes, historicamente constituídas, em jogo e que, seguindo a sugestão de Ritvo, parecem estar de alguma forma associadas ao tipo de relação entre o homem e a natureza que a ciência moderna produziu. O antigo temor da natureza nos tornava potencialmente animais, em perigo de desumanização quando em contato com animais de estimação. O atual paradigma de controle da natureza nos permite controlar tais animais a ponto de vê-los como humanizados. Se os próprios animais não mudam, certamente a sociedade e as ideias dos homens é que terão mudado.

Para Thomas (1988), três traços distinguiam o animal de estimação dos outros animais. Em primeiro lugar, ele tinha permissão de entrar na casa; em segundo, possuía um nome; e, em terceiro, não era comida. No caso dos animais de estimação, quanto mais mimados, maior a possibilidade de um nome humano. Essa foi uma tendência acentuada no século XVIII, indicando o vínculo mais estreito entre o animal e seu dono. "Por volta de 1700", diz o autor, "com freqüência os mascotes eram melhor alimentados que os empregados" (p. 141), tendência que dá origem ao episódio que Darnton (1986) analisa como 'o grande massacre de gatos', quando alguns tipógrafos franceses matam uma grande quantidade desses animais em função do que avaliam como maus-tratos, sobretudo aos aprendizes, vindos da parte dos patrões, que tratavam e alimentavam melhor seus gatos do que seus empregados. Como forma de rebelião, os tipógrafos matam uma série de gatos, começando pela gata preferida da esposa do patrão, em um teatro que era, ao mesmo tempo, drama e ritual no qual julgavam e condenavam os gatos no lugar dos patrões.

Para Leach (1983), os animais de estimação são uma categoria ambígua na interseção entre o humano e o animal. Na verdade, seriam ambos ao mesmo tempo. A regra que restringe o consumo de sua carne, ou, dito de outra forma, a regra que permite tomar como animal de estimação aquele que não será comido (espécie, sobretudo, mas também indivíduo), é decorrente, segundo o autor, de uma sobreposição estrutural entre o animal de estimação e a relação de parentesco mais próxima - a de irmão/ã - guardada pelo tabu do 
incesto. Assim, pela analogia entre sexo e comida, o autor afirma que o animal de estimação é parte da família e, portanto, não pode ser comido.

Segundo Ritvo (1994), no estabelecimento da taxonomia científica, muitos elementos da cultura popular foram levados em consideração e posteriormente abandonados aos poucos. O gato era considerado simultaneamente doméstico e selvagem, isto é, apenas parcialmente doméstico. Tomando-se o modelo de Leach (1983), os animais em posição ambígua, como é o caso do gato, seriam caracteristicamente animais tabu, isto é, sagrados e sobrenaturais. A ligação do gato com a feitiçaria, conforme apontado por Darnton (1986), assinala essa característica. Tais animais são aqueles preferidos para situações rituais e isso, em parte, explica por que aparecem como animais sacrificiais em ritos europeus, conforme mostrado acima. Para Leach, o tabu envolve, ainda, as questões alimentares. Assim, o animal de estimação, tomado como uma extensão da humanidade, não pode ser consumido, na medida em que isso seria canibalismo. Esse é claramente o caso do cão no mundo Ocidental. Seria o caso do gato?

\section{Comestibilidade}

Pode-se discutir se gatos são comestíveis ou não no Brasil. Há uma jocosidade recorrente sobre o churrasquinho de gato, ou filé miau, que se refere à obscura procedência da carne servida em espeto e churrasqueada na rua por vendedores ambulantes. Outra relação jocosa diz que gatos viram tamborim, instrumento de percussão largamente utilizado nas baterias de escolas de samba que produziria melhor som quando fabricado com couro de gato. Há, ainda, a expressão "comprou gato por lebre", que se refere à comestibilidade da segunda e não do primeiro.

Gatos não são comida e, portanto, seguindo o modelo leachiano, seriam inconscientemente tabu. Contudo, os animais que são conscientemente tabu, como é o caso do porco, podem ser comidos em situações rituais específicas. As refeições que marcam algumas festas religiosas brasileiras (Natal, Ano Novo, ciclo junino, Semana Santa) substituem o consumo de carne de boi pela de outros animais, o que 
demonstra seu caráter ordinário. O churrasco, contudo, como evento festivo que congrega amigos e parentes, é marcado pelo consumo dessa carne em quantidades que ordinariamente não são consumidas, dando o tom ritual da festa. Como a carne de gato só é possivelmente consumida churrasqueada, através de um engano da parte do consumidor que "compra gato por lebre", isto é, gato por gado, devemos nos perguntar o quanto esse consumo é um tabu consciente e o quanto ele é inconsciente. O risco do consumo de carne de gato é eminente para quem come o churrasco de rua (gato), sem se discutir aqui o quanto o risco é real e o quanto é imaginário. Contudo, a jocosidade é uma espécie de alerta: tal carne não pode ser consumida conscientemente. Para evitar o risco, deve-se evitar o consumo da carne vendida pelos ambulantes de rua. Assim, pode-se concluir que se trata de um tabu inconsciente. Não há venda de carne de gato nos mercados ordinários, portanto ela não é comida, mas algumas pessoas não se importam se a carne dos ambulantes é bovina ou felina (real ou imaginariamente). É nessas situações que sugiro que a carne felina seja vista como caça dentro do modelo leachiano. A caça é, nesse modelo, tão ambígua quanto o animal de estimação.

Há indícios que apontam para outras ambiguidades do gato. Além dos aspectos sobrenaturais e de consumo, diz-se comumente que ele é um animal que caça (ratos), característica dos animais selvagens. Não obstante, é também um animal de estimação e, portanto, humanizado. Seu status é ambíguo. Decorre dessa ambiguidade que se brinque com a possibilidade de ingesta da carne de gato, brincadeira que não é feita com relação ao cachorro, o que indica que um seria mais sagrado do que o outro. Leach (1983) sugere que não se separem, simplesmente, os animais em sagrados e profanos, mas que se observe que alguns são mais sagrados do que outros.

Seguindo a proposta leachiana, o gato estaria na interseção entre duas posições em três séries: ele seria ao mesmo tempo irmãcasa-animal de estimação e vizinho-campo-caça. Em oposição ao cão (irmã), ele seria vizinho, portanto possivelmente consumível. A caça é, segundo o autor, por definição, uma posição ambígua. O ditado que diz "levar gato por lebre" coloca os felinos na posição de substitutos de um característico animal de caça, a lebre. O coelho, aparen- 
tado da lebre, é ainda mais ambíguo, porque pode ser caça, praga, animal criado em fazenda e animal de estimação ao mesmo tempo. Os animais de caça são comestíveis, como alguns animais criados em fazenda; as pragas e os animais de estimação não o são. Encerrando as séries em três grandes grupos, o autor indica que animais de estimação e animais de caça formam um conjunto que está na interseção entre humanos/animais domésticos (a), de um lado, e animais/ bichos selvagens (b), de outro, cada polo formando um oposto: (a) humano/(b) animal e (a) doméstico/(b) selvagem. O animal de estimação se encontra na interseção entre humano/animal; e a caça, na interseção entre doméstico/selvagem.

\section{O felino feminino}

Uma das facetas simbólicas dos animais é sua associação com masculinidades e feminilidades. Como afirma Motta (2008, p. 201), "se tudo, na prática simbólica, pode ser classificado como masculino ou feminino, também as representações sobre animais veiculam representações de gênero". O exemplo mais famoso na antropologia contemporânea é, certamente, o galo balinês. Geertz (1989, p. 283284) percebe simbolismos de gênero quando analisa a briga de galos em Bali:

Bateson e Mead sugeriram até [...] que os galos eram vistos como pênis separados, autofuncionáveis, órgãos genitais ambulantes, com vida própria. [...] O fato de que eles são símbolos masculinos par excellence é tão indubitável e tão evidente para os balineses como o fato de que a água desce pela montanha.

A partir de Geertz (1989), Motta (2008, p. 212) foi capaz de perceber processo similar em competições de pássaros canoros em Florianópolis:

A identidade entre homem e curió é inequívoca. O curió, especialmente o 'curió-valente', preparado para torneios de fibra, incorpora atributos de masculinidade extremamente valorizados nesse contexto: valentia, fibra, poder e capacidade de enfrentamento e intimidação. 
Diversos autores (DaMatta e Soárez, 1999; Darnton, 1986; Leach, 1983) associam o gato a questões de gênero. Leach (1983) aponta que na Inglaterra cão e gato são, respectivamente, masculino e feminino. O uso comum no inglês, como no português, é de indicação de gênero masculino para o cão (fem. cadela). No português, gato é masculino, mas no inglês ele seria feminino, apresentando-se um termo particular (tom cat) para o gato macho. E, da mesma forma que em português, cão e gato trazem, quando juntos, a ideia de uma briga que, na língua inglesa, estaria restrita a maridos e mulheres. Leach também aponta que gato é um insulto, ao passo que no Brasil trata-se de elogio. O insulto, em língua inglesa, estaria vinculado, ainda, ao pelo pubiano feminino, remetendo ao contexto sexual do gato, como Darnton (1986) também aponta.

Assim como a esfera de atuação feminina é a esfera doméstica, o gato também era considerado, segundo Darnton (1986), um animal da casa e relacionado ao dono dessa. Por extensão de sua relação com duas características tão marcantemente femininas como a feitiçaria e o ambiente doméstico, o gato, indica o autor, também era associado ao sexo. Na gíria francesa, o órgão sexual feminino era denominado com palavras que significam "gato/a". Mulheres e gatos eram identificados em provérbios populares. "Em toda parte os gatos sugeriam fertilidade e sexualidade feminina" (Darnton, 1986, p. 127). No episódio do 'grande massacre de gatos', a relação entre gato e feminilidade emerge quando Darnton aponta que a gata preferida da esposa do patrão foi a primeira a ser morta, sinalizando metaforicamente a dominação sexual da esposa por parte dos tipógrafos rebelados.

Enquanto em Bali os galos são pênis metafóricos (Geertz, 1989), no Brasil os pênis são pintos ou perus, nunca curiós. Na França (Darnton, 1986) e na Inglaterra (Leach, 1983) as vaginas são gatas, ao passo que no Brasil as gatas são mulheres (DaMatta e Soárez, 1999). O gato, em língua francesa e inglesa, nomeia a própria genitália feminina, o que não acontece no Brasil. Ao que parece, como aponta Leach (1983), não é qualquer animal que se presta, como categoria, a relações metafóricas e/ou metonímicas. O gato está simbolicamen- 
te associado ao feminino, embora não seja o único animal nessa posição. Conforme DaMatta e Soárez (1999), cobras, vacas, borboletas e cabritas, animais do jogo do bicho, são metáforas de condutas morais femininas no Brasil: a cobra e a cabrita sinalizam sexualidade, ao passo que a vaca representa a maternidade e a borboleta é uma moça matrimoniável.

No fundo, o povo vê a borboleta como [mulher] 'matrimoniável' em oposição à cabra, que é uma presa legítima. As primeiras seriam moças de família (e da casa); as segundas, moças da rua. [...] A vaca, já vimos, é o bicho símbolo da maternidade e do leite. É esposa, sogra e mãe. Já a cobra é a mulher da rua experiente e sagaz (p. 150).

Classificando os animais do jogo do bicho em termos de gênero, os autores chegam aos seguintes conjuntos: a) masculino: águia, touro, leão, elefante, galo e peru (estes últimos metafóricos da genitália masculina); b) feminino, subdividido em b.1) casa (borboleta e vaca) e b.2) rua (cabra, gato e cobra); e c) "coluna do meio" de "bichos liminares", como chamam os autores a zona de interseção na qual não se pode definir estritamente nem masculino nem feminino, ou seja, os animais que representam uma espécie de gênero ambíguo, ligado à homossexualidade vista como um masculino afeminado ou a uma masculinidade não hegemônica: veado, pavão, avestruz, cabra e, novamente, gato. É interessante observar que não há ambiguidade feminina, apenas masculina.

Não obstante se tratar, a meu ver, de uma classificação que confunde gênero e sexualidade, os autores apresentam-na apenas em termos de "projeções sexuais", "potencialidades sexuais" e "conotação sexual". O gato aparece, inexplicavelmente, tanto no conjunto b.2, que se refere ao feminino "da rua", quanto no conjunto c, que se refere a uma pretensa zona de interseção entre masculino e feminino. Digo inexplicavelmente porque os autores, de fato, não o explicam. O veado é, segundo eles, o animal que, "no Brasil, designa o homossexual passivo masculino" (DaMatta e Soárez, 1999, p. 151). O pavão, referido como vaidoso, apresentaria uma característica feminina. A cabra é um homem subordinado, "um capanga", tanto quanto "uma moça livre". O avestruz "é às vezes chamado de 'bi- 
cha', fato que talvez se explique por se tratar de um bicho passivo no embate, que, como o veado, corre velozmente, não podendo ser alcançado" (DaMatta e Soárez, 1999, p. 151). Não se explica a alocação do gato na "coluna do meio", a não ser através dos adjetivos "dissimulado, sinuoso; lânguido", de onde se conclui que sejam, conforme os exemplos acima, considerados como características femininas, corroborando a noção de que seria um animal relacionado ao feminino.

\section{Bichanos, gatas e gatunos}

Segundo DaMatta e Soárez (1999), na sociedade brasileira 'animal' e 'bicho' são categorias distintas: a primeira é englobada pela segunda, que inclui, além dos animais, pessoas e seres sobrenaturais. Mauss (2003, p. 74) afirma que os espíritos que auxiliam o mágico "têm geralmente formas animais, reais ou fantásticas". Como categoria classificatória, 'bicho' seria usada para coisas ambíguas, exóticas ou indefinidas, dizem os autores. Acredito que 'bichano', palavra que também define o gato, parece apontar para essa ambiguidade do animal definido, que, além de tudo, é sobrenatural, "tem sete vidas", dá má sorte e é animal sacrificial.

Em uma série de associações entre bichos e situações das quais se pode depreender um palpite para "jogar no bicho", DaMatta e Soárez (1999) recolhem as seguintes associações acerca do gato: é animal que pega ratos, associado a ladrões e à traição. Segundo os autores,

O gato, como um tigre em pequena escala, também ‘só pega rato à traição' e, mesmo doméstico, é um animal que fica ao lado 'do fogão' (onde dorme), preferindo os espaços marginais e ambíguos da casa, como a cozinha (zona na qual os alimentos se transformam em comida), a varanda, os umbrais de portas e janelas e, naturalmente, os telhados (todos situados entre a dimensão interna e externa da moradia). Ademais, quando o gato está na rua, ele vaga com outros gatos, formando bandos que, perambulando pela noite, são uma metáfora perfeita para os bandos de marginais que infestam a rua nas grandes cidades brasileiras (p. 135). 
É interessante observar toda uma gama de associações que marcam o gato como animal ambíguo, portanto de pouca confiança. Se 'bichano' marca o gato como 'bicho', que pode ser sobrenatural, 'gatuno' marca o ladrão como gato e o gato como ladrão, posto que ambos trafegam pelos mesmos espaços físicos, já tornados espaços sociais (Bourdieu, 1999). Dentro de casa, esse gato imaginado prefere o ambiente feminino e subalterno da cozinha, tão ambígua quanto as próprias mulheres sob a ótica da dominação masculina (Bourdieu, 2003). Mas, ao contrário dessas, trafega livremente entre a casa e a rua, nunca apenas em uma. Na rua e nas interseções entre essa e a casa (muros, telhados, umbrais), o gato se assemelha a uma figura caracteristicamente masculina: o ladrão. Além de tudo, gatos gostam de leite, alimento considerado por DaMatta e Soárez (1999) como feminino.

Em oposição ao gato está o cachorro. Segundo esses autores, se o gato está para o tigre numa série de oposição doméstico/selvagem, o cão está para o leão, um animal nobre. Assim, rei da selva: 'rei do lar'. “O cachorro está para a parte interna (sagrada, 'humana', íntima, frágil, secreta e feminina) da casa como o gato está para suas partes externas, que são públicas, visíveis e masculinas" (DaMatta e Soárez, 1999, p. 135-136). Isso, contudo, não faz do cão animal feminino. Segundo os autores, o latido é masculino, ao passo que o miado é feminino. No caso do gato, afirmam, a relação com o universo feminino é tanto metafórica quanto metonímica, na medida em que as mulheres podem ser gatas.

Em um esforço classificatório, DaMatta e Soárez (1999) constroem várias séries de oposição para os animais que constituem o jogo do bicho. Como meu interesse é uma análise simbólica do gato, este material provou-se bastante rico em termos dos esquemas classificatórios operantes na sociedade brasileira. Ao usar as análises dos autores acerca do jogo, não opero, necessariamente, uma generalização das associações para toda a sociedade brasileira, mas uma apropriação de tais ideias como parte do simbolismo envolvendo o gato no Brasil. 
Segundo os autores, cães e gatos são animais ativos, pois são caçadores, embora caçadores domésticos. O cão é apontado como um intermediário entre as classes superiores e as inferiores, posto que cumpre ordens e protege o "patrão". O cão trabalha, o gato rouba (como diz o senso comum: "um olho no gato e o outro no pei$\left.\mathrm{xe}^{\prime \prime}\right)$. A relação canina com o humano, portanto, seria de solidariedade, ao passo que a relação felina seria de traição, na medida em que o senso comum brasileiro aponta que o gato não gosta das pessoas, mas da casa onde vive. Pode-se sugerir que seria visto como um animal mais territorial do que afetivo. Em outra série comparativa, os autores indicam que, em termos de potencialidades sexuais, o gato estaria associado a um feminino da rua, libertino, o que corrobora a ideia de que não é metáfora de afeto.

Para DaMatta e Soárez (1999), cães de raça, gatos, cavalos e vacas de leite são sinais de superioridade social. Em oposição ao cão de raça estaria o vira-lata, ao cavalo estaria o burro e à vaca estaria a cabra, cada qual relacionado a um estrato social diferente. Não há oposição ao gato, mas é interessante perceber como Darnton (1986) analisa 'o grande massacre de gatos' a partir de uma ótica da revolta de classe na qual os gatos estavam associados aos patrões burgueses, mais bem tratados do que os aprendizes.

Essa lógica de associações por estratificação social não é contemplada na análise de Leach (1983), especialmente voltada à compreensão de aspectos simbólicos relacionados ao ritual e à sacralidade. Há que se questionar, portanto, se as abordagens são complementares ou antitéticas. Nesse sentido, creio que o simbolismo envolvendo o gato está muito mais fortemente ancorado em aspectos rituais, dadas suas associações com o sobrenatural, do que em uma estratificação social. No Brasil contemporâneo, parece-me que o gato não é tão associado às elites quanto o cachorro, especialmente os de pedigree, embora este não seja totalmente associado àquelas. Afinal, a "vida de cão" não é, na expressão popular, uma vida confortável ou luxuosa.

Em termos de sacralidade, cães e gatos seriam animais ambíguos, pois cão é sinônimo de capeta, ao passo que os autores associ- 
am o gato, inexplicavelmente, aos anjos. Nesse caso, creio que a análise foi infeliz. A abordagem de Leach (1983) apontaria que cães e gatos são animais sagrados e que as operações de inversão marcam essa sacralidade: se o cão é o melhor amigo do homem, no Brasil é insulto usado para um homem canalha; se o gato é traidor e ladrão, é elogio à pessoa bonita. Contudo, o cão seria mais sagrado do que o gato, posto que a interdição do consumo da carne daquele é maior do que a deste.

Não obstante, Ritvo (1987) afirma que no século XVIII inglês as características morais atribuídas ao cão eram outras. Em vez de lealdade e afeto, pinturas e gravuras satíricas sugeririam que o cão representava bestialidade, vulgaridade e subversão. A lealdade ao mestre humano não era questionada, mas alguns apontavam o cão como malcomportado com a própria espécie, egoísta, cruel e injusto. Se fosse possível uma generalização do contexto oitocentista inglês ao contemporâneo brasileiro, ter-se-ia que se pensar em um processo de continuidade entre o cão-capeta e o cão como animal egoísta, cruel e injusto, em vez de um processo de inversão, como foi indicado acima. O mesmo deveria valer para o cão como categoria de insulto no Brasil. É interessante, ainda, salientar que Leach (1983) indica cão (dog) como uma inversão de deus (god).

\section{Um animal limpo e independente?}

Em seu clássico Pureza e perigo, Mary Douglas (1976) indica que a noção de poluição não é física, mas simbólica. Chamando de materialismo médico o debate que indicava a carne suína como imprópria para consumo devido às suas qualidades físicas nocivas e indicando o porco como animal sujo, a autora aponta como as noções de limpeza e sujeira, pureza e poluição são categorias simbolicamente construídas que não demandam uma realidade física.

O gato no Brasil é percebido pelo senso comum como um animal "limpo" (Oliveira, 2006), mas o que isso significa? A noção de limpeza do gato é sustentada por dois argumentos gerais do senso comum brasileiro: em primeiro lugar, ele "toma banho" quando mantém o hábito natural da espécie de lamber todo o corpo sistema- 
ticamente; em segundo lugar, o gato enterra seus excrementos. O "banho" do gato, associado à ideia de que gatos não gostam de água, leva, na prática, a que esses animais de estimação não sejam banhados com água e sabão por seus donos, ou seja, em geral, menos banhados do que os cães de estimação. Oliveira (2006), em pesquisa de campo realizada em pet shops, indica que o público preferencial do serviço de "banho e tosa" é o cachorro e que há poucos gatos. Segundo ela,

Os principais clientes do 'banho e tosa' são os proprietários de cães, seja pelo fato de existirem mais cães do que gatos classificados como animais de estimação nos grandes centros urbanos do país, seja devido à crença de que 'gatos não gostam de tomar banho' ou que 'se limpam com as próprias lambidas'. [...] Os gatos, como já foi dito, são raros. Porém, os poucos que tomam banho nas Pet Shops geralmente dão mais trabalho para os tosadores e banhistas pois, como não estão habituados com o banho, costumam se comportar de forma agressiva e arredia, o que pode ser comprovado ao analisar-se a tabela de preços de um banho e tosa. [...] Os gatos encontram-se numa categoria diferenciada e, apesar de serem animais de porte pequeno, geralmente os preços referentes ao banho e tosa são compatíveis com os dos cães de grande porte (p. 57-59).

Em outras palavras, a autora indica que não é costume banhar os gatos em pet shops, e, já que é costume banhar os cães, podese concluir daí que os gatos tampouco são banhados nas casas onde vivem. Eles não seriam banhados porque não há necessidade e, por uma falta de adestramento do animal, quando banhados, resistem. Essa resistência faz com que o preço do banho em gatos seja proporcionalmente maior do que em cachorros. Em termos econômicos, haveria que se perguntar se o preço não se torna uma falta de estímulo ao proprietário.

Se um animal jamais ou raramente é banhado na forma humana, ou seja, com água e sabão, ele pode ser considerado limpo? Como não se trata de materialidade, a questão não é, certamente, a limpeza física, mas a interpretação do hábito natural da espécie como um correlativo de um hábito humano (embora não somente humano): 
tomar banho. Assim, enquanto os cães têm que ser banhados por humanos, os gatos banham-se a si mesmos, o que é um primeiro indicativo da noção de que são independentes.

Quanto aos excrementos, os donos de cães devem recolhê-los das ruas e calçadas quando levam seus cães "para passear", uma metáfora comumente usada no lugar de "excretar". Os gatos, por outro lado, enterram seus excrementos. Quando o animal não tem acesso a terra, há um substituto industrializado, até onde pude verificar amplamente disponível nos pet shops e supermercados, chamado "areia sanitária". A substância granulada é disponibilizada em uma caixa para o animal, que, novamente por hábito inato, a utiliza para depositar seus excrementos. A areia sanitária absorve a urina e o gato cobre, sozinho, a urina e as fezes com a areia. Esses hábitos são, eu sugeriria, interpretados como indicativos da limpeza do gato e de sua independência. Além disso, na qualidade de caçador de ratos, conforme já indicado nesta obra, o gato se torna simbolicamente um purificador do ambiente, afastando um vetor de doenças. Afinal, um animal que toma banho, produz uma espécie de fossa e afasta ratos só poderia ser considerado limpo.

Outro aspecto que pode ser analisado acerca das representações contemporâneas sobre o gato no país é a ideia de que ele é um ser independente. Como afirmam Saito et al. (2002, p. 125),

ao mesmo tempo, por suas características que foram relacionadas com azar e doenças, muitas pessoas os vêem como uma espécie de ameaça; outros, devido à independência do gato que está entre o limiar de animal selvagem e doméstico, o vêem como uma espécie arrogante e prepotente.

A passagem acima indica representações acerca do gato na sociedade brasileira. Como desenvolvido ao longo deste ensaio, o gato aparece mais uma vez como ser liminar (Turner, 1974), anômalo ou ambíguo (Leach, 1983), na medida em que não pertence nem à esfera selvagem nem à doméstica, apresenta poderes mágicos (azar) e pode provocar doenças. Se Thomas (1988) afirma que o gato é introduzido nas residências inglesas como uma espécie de agente sanitá- 
rio que combate ratos, portanto doenças, hoje parece que essa função perdeu vigor e o cientificismo vigente tem condenado os felinos como vetores de doenças, um papel coerentemente relacionado por Saito et al. (2002) na passagem acima à má sorte. Além de vetor de raiva (Genaro, 2010) e toxoplasmose (Saito et al., 2002), o gato seria causador de asma e alergias (Hyams, 1972).

A afirmação de independência dos gatos, como é frequente no senso comum, é sustentada por argumentos distintos, factuais ou imaginários: caça e se alimenta sozinho (selvagem), se limpa sozinho, sai da residência e retorna sozinho, permanece sozinho dentro da residência (doméstico). Todas as ações elencadas indicam, propositalmente, que o gato não depende de humanos para sobreviver, não obstante, a medicina veterinária aponta como esse grau de (in)dependência é relativo, posto que é determinado pelo tipo de relação que o animal mantém com os humanos. Conforme Genaro (2010, p. 187-188),

O grau de dependência (dos humanos) que o gato apresenta pode variar amplamente e, nesse aspecto, observa-se importante detalhe a ser considerado, que são as populações ferais, muito comuns entre gatos. Um gato feral pode ser definido de várias maneiras, mas fundamentalmente essa condição de ser feral, ou não, dependerá de sua relação com a população humana. Sua dependência, especialmente para alimento e abrigo, pode ser graduada, concebendo-se a partir de grande dependência (como, por exemplo, um gato mantido num apartamento, que dependerá de seu proprietário para toda e qualquer necessidade) até um gato que nasceu e se reproduz livremente numa ilha ou floresta, totalmente afastado do contato humano (exemplificado o animal feral típico, stricto sensu), e dentre esses dois extremos há ampla gama de gradações.

Não se está, portanto, no plano da factualidade quando se afirma a independência dos gatos, mas no plano das representações. Eu gostaria de sugerir que a ideia de que o gato é um animal independente - forjada a partir da interpretação de alguns de seus modos, mas, sobretudo, na forma como os humanos se relacionam com eles e na comparação com outros animais, especialmente o cão - 
contribui para o abandono de gatos nas ruas, que formam colônias urbanas tão comuns e invisíveis aos transeuntes que parecem ser "um elemento 'natural' das ruas", como afirma Genaro (2010, p. $188)$.

A questão da (in)dependência do gato é interessante na medida em que ela toca no tipo de relação entre natureza e cultura que uma sociedade imagina manter. Como aponta Ritvo (1987), a emergência da ciência parece criar um paradigma de dominação da natureza. Nesse sentido, a popularização dos animais de estimação é equacionada pela autora com uma nova organização social. A dominação da natureza é expressa de diversas formas e a criação de novas raças de cães, expostas e premiadas em concursos criados exclusivamente para essa finalidade, é um exemplo disso. Outra forma de dominação da natureza é criar um animal totalmente dependente de humanos, como é o caso dos animais de estimação que vivem em casas e apartamentos, dependentes de seus donos para ter acesso à alimentação, à rua, à água, entre outros.

Gostaria de sugerir, portanto, que ver o gato como dependente é colocar-se no paradigma cientificista de supremacia humana sobre a natureza, mas também é vê-lo como um animal de estimação nas séries analíticas descritas por Leach (1983), conforme elencadas anteriormente, em que o animal está mais próximo do humano. Ao contrário, ver o gato como independente é colocá-lo mais próximo do selvagem. Quando se diz que o gato não tem afeto pelo dono, mas pela casa, é também um aspecto selvagem do gato que é enfocado, salientando-se uma percepção de que ele não depende de humanos. A relação entre gato e traição, conforme apontada por DaMatta e Soárez (1999), parece corroborar essa independência que é, no mais, uma incapacidade de controlar o animal. É necessário, entretanto, se perguntar por que a pretensa independência do gato é correlacionada por algumas pessoas, conforme citação anterior de Saito et al. (2002), com arrogância e prepotência: possivelmente, porque demonstra a incapacidade de controle total da natureza pelo homem. 


\section{Considerações finais}

No presente ensaio tentou-se efetuar uma espécie de síntese dos aspectos simbólicos relacionados ao gato encontrados na parca literatura historiográfica e antropológica que menciona especificamente esse animal. Amparado em tal material, o trabalho buscou apresentar análises nas quais o gato figura como animal ambíguo, portanto anômalo. Essa ambiguidade, lida à luz da teoria leachiana, permite explicar por que o animal foi associado a práticas mágicas e transformado em animal sacrificial em ritos europeus. Em ambos os casos, a teoria leachiana permite perceber nos animais tabu e nos animais de estimação uma condição anômala e ambígua.

Outro aspecto apontado neste trabalho foi a correlação entre o gato e o feminino. Tanto na França (Darnton, 1986) quanto na Inglaterra (Leach, 1983), o gato é associado ao feminino e à sexualidade. No Brasil, a associação não é direta, mas DaMatta e Soárez (1999) apontam alguns aspectos do gato que podem ser relacionados ao feminino. Animal diabólico relacionado a feiticeiras e à lua, especialmente quando preto como a terra, o gato aparece constantemente cercado de símbolos femininos.

No Brasil, DaMatta e Soárez (1999) indicam como nossa sociedade faz uma leitura do gato como animal de espaços liminares (Turner, 1974). Busquei, na medida do possível, apresentar outras representações contemporâneas relacionadas ao gato na sociedade brasileira: um animal que é visto como limpo e independente. Essas qualidades atribuídas aos gatos fazem parte do imaginário nacional sobre eles e corroboram as análises simbólicas sustentadas por Leach (1983) e Douglas (1976). Ora puro, ora impuro; ora doméstico, ora selvagem; ora dependente, ora independente; ora mágico, ora bode expiatório; o gato parece guardar uma posição anômala para além de ser atualmente, sobretudo, um animal de estimação.

Ainda assim, o caminho percorrido até este posto não o exclui, atualmente, dos maus-tratos que pareciam tão característicos do universo medieval, sob uma ótica dos direitos dos animais. Se não se queimam mais gatos em procissões religiosas, ainda se os matam em colônias de animais abandonados nas grandes cidades (Saito et al., 
2002). Esse não foi considerado um aspecto ritual da morte de gatos no presente trabalho, mas acredito que mereça considerações futuras.

\section{Referências}

APROBATO FILHO, Nélson. 2006. O couro e o aço - sob a mira do moderno: a 'aventura' dos animais pelos 'jardins' da Paulicéia, final do século XIX/início do século XX. Tese (Doutorado em História) - Universidade de São Paulo, São Paulo, 2006.

BOURDIEU, Pierre. Efeitos de lugar. In: (Coord.). A miséria do mundo. Petrópolis: Vozes, 1999. p. 159-166. . A dominação masculina. Rio de Janeiro: Bertrand, 2003.

COHEN, Esther. Animals in Medieval Percpetions: The Image of the Ubiquitous Other. In: MANNING, Aubrey; SERPELL, James. Animals and Human Society: Changing Perspectives. London: Routledge, 1994. p. 59-80.

DAMATTA, Roberto. Carnavais, malandros e heróis: para uma sociologia do dilema brasileiro. Rio de Janeiro: Rocco, 1997.

DAMATTA, Roberto; SOÁREZ, Elena. Águias, burros e borboletas: um estudo antropológico do jogo do bicho. Rio de janeiro: Rocco, 1999.

DARNTON, Robert. Os trabalhadores se revoltam: o grande massacre de gatos na Rua Saint-Séverin. In: - O grande massacre de gatos e outros episódios da história cultural francesa. Rio de Janeiro: Graal, 1986. p. 103-139.

DOUGLAS, Mary. Pureza e perigo. São Paulo: Perspectiva, 1976.

GEERTZ, Clifford. Um jogo absorvente: notas sobre a briga de galos balinesa. In: . A interpretação das culturas. Rio de janeiro: Livros Técnicos e Científicos, 1989.

GENARO, Gelson. Gato doméstico: futuro desafio para controle da raiva em áreas urbanas? Pesq. Vet. Bras., v. 30, n. 2, p. 186-189, fev. 2010.

GUIMARÃES, Antonio Sérgio Alfredo. O insulto racial: as ofensas verbais registradas em queixas de discriminação. Estudos Afro-Asiáticos, n. 38, dez. 2000. Disponível em: < http://www.scielo.br/ scielo.php?script $=$ sci_arttextspid $=$ S0101546X2000000200002 $\overline{\text { glng }}=$ pt\&nrm=iso >. Acesso em: 05 maio 2011.

HUBERT, Henri; MAUSS, Marcel. Ensaio sobre a natureza e a função do sacrifício. In: MAUSS, Marcel. Ensaios de Sociologia. São Paulo: Perspectiva, 2001. p. 141-227.

HYAMS, Edward. Animals in the Service of Man: 10.000 Years of Domestication. London: J. M. Dent \& Sons Ltda., 1972.

\section{ILHA}


KULICK, Don. Animais gordos e a dissolução da fronteira entre as espécies. Mana, Rio de Janeiro, v. 15, n. 2, p. 481-508, 2009.

LEACH, Edmund. Aspectos antropológicos da linguagem: categorias animais e insulto verbal. In: DAMATTA, Roberto (Org.). Edmund Leach. São Paulo: Ática, 1983. p. 170-198. (Coleção Grandes Cientistas Sociais).

MAUSS, Marcel. Esboço de uma teoria geral da magia. In: . Sociologia e Antropologia. São Paulo: Cosac Naify, 2003. p. 49-181.

MOTTA, Flávia de Mattos. Curió valente: representações de gênero em competições de pássaros canoros. Cadernos Pagu, Unicamp, v. 30, n. 1, p. 199229, jan./jun. 2008.

OLIVEIRA, Samantha Brasil Calmon de. 2006. Sobre homens e cães: um estudo antropológico sobre afetividade, consumo e distinção. Dissertação (Mestrado em Sociologia ) - Universidade Federal do Rio de Janeiro, Rio de Janeiro, 2006.

RITVO, Harriet. The Emergence of Modern Pet-keeping. Anthrozoös, v. 1, n. 3, p. 158-165, 1987.

. Animals in Nineteenth-Century Britain: Complicated Attitudes and Competing Categories. In: MANNING, Aubrey; SERPELL, James. Animals and Human Society: Changing Perspectives. London: Routledge, 1994. p. 106-126.

SAHLINS, Marshall. Cultura e razão prática. Rio de Janeiro: Zahar, 1979.

SAITO, Carlos H. et al. A matança dos gatos na UnB: estilhaços da distância entre homens e animais. Rev. Eletrônica Mestr. Educ. Ambient., v. 9, p. 124-136, jul./dez. 2002.

SERPELL, James. Pet-Keeping in Non-Western Societies: Some Popular Misconceptions. Anthrozoös, v. 1, n. 3, p. 166-174, 1987.

SERPELL, James; PAUL, Elizabeth. Pets and the Development of Positive Attitudes to Animals. In: MANNING, Aubrey; SERPELL, James. Animals and Human Society: Changing Perspectives. London: Routledge, 1994. p. 127-44.

SPERBER, Dan. Pourquoi les animaux parfaits, les hybrides et les monstres sont-ils bons à penser symboliquemente? L'Homme, v. 15, n. 2, p. 5-34, 1975.

THOMAS, Keith. O homem e o mundo natural: mudanças de atitude em relação às plantas e aos animais (1500-1800). São Paulo: Cia. das Letras, 1988.

TURNER, Victor. O processo ritual: estrutura e antiestrutura. Petrópolis: Vozes, 1974.

2005.

. Floresta de símbolos: aspectos do ritual Ndembu. Niterói: Ed. UFF,

Recebido em: 18/09/2011

Aceite em: 29/10/2011

ILHA

volume 12 - número 2

259 